\title{
Investigating Rainfall Trend and Monitoring Meteorological Drought in a Himalayan Watershed of India
}

\author{
Alok Kumar Mishra ${ }^{1}$ and Anil Kumar²* \\ ${ }^{1}$ Department of Soil, Water, Land Engineering and Management, Sam Higginbottom Institute of Agriculture \\ Technology and Sciences, Allahabad (U.P), India \\ ${ }^{2}$ Department of Soil and Water Conservation Engineering, G.B. Pant University of Agriculture \& Technology, \\ Pantnagar-263145, Uttarakhand, India \\ Email: anilkumar_swce61@rediffmail.com
}

\begin{abstract}
Assessment of rainfall trend and monitoring meteorological drought and wet conditions are very important in dealing with agricultural planning and water resources management under the influence of changing climate in the Himalayan region. This study was conducted to assess rainfall trend and monitor the drought and wet pattern at four stations, namely Naula, Kedar, Chaukhutia and Mehalchauri, located in the upper Ramganga River catchment in Uttarakhand state of India in the central Himalayan region. Rainfall trend analysis at these stations was carried out using MannKendall test and Sen's slope estimator. Standardized Precipitation Index (SPI) at multiple time scales of 1-, 3-, 6-, 9-, 12- and 24-months was used to assess meteorological drought and wet pattern at Naula station. Results have indicated a significantly downward trend in December and postmonsoon season and an upward trend in September at Naula station. Significantly downward trend was also observed in July, December and monsoon season at Kedar station, and in June, July, August, monsoon and annual data series at Chaukhutia station. No significant trend was observed at Mehalchauri station. Study also revealed that there are more chances of occurrences of mild drought and wet conditions and only meager chances of moderate drought and wet conditions during monsoon season. However, the chances of severe and extreme drought and wet conditions are almost negligible. Therefore, efforts must be made to harvest the excess water during the wet periods and utilize the same during the periods of mild and moderate drought for drinking, household activities and irrigation purposes
\end{abstract}

Keywords: Trend analysis, deficit rainfall, drought and wet spell, SPI, Himalayan region.

\section{Introduction}

Drought is recognized as an environmental disaster and in recent times it has attracted the attention of environmentalists, ecologists, hydrologists, meteorologists, geologists and agricultural scientists. Drought occurs virtually in all climatic zones and is mostly related to the reduction of precipitation amount received over an extended period of time, usually a season or a year. Due to the growth of population and expansion of agricultural and industrial sectors, the demand for water has increased manifolds and the water scarcity has been occurring almost every year in many areas of the world.

Drought generally occurs when an area does not receive considerable amount of rainfall for a continuous period of time [1]. There are two main definitions of drought: conceptual and operational. Conceptual definition describes the drought in relative terms as a long dry period; whereas operational definition attempts to identify the onset, severity and duration of drought for a given return period [2]. The UN convention to combat drought and desertification [3] defined drought as the natural phenomenon that occurs when precipitation falls below normal recorded levels, which produces hydrological imbalances affecting the land resource production systems. Globally, drought (covering 7.5\% land area) is the second most geographically extensive hazard after floods (11\% of the earth's land area). The percentage of area affected by serious droughts has doubled from 1970 to the early 2000. The period of unusual dryness or drought is a normal feature of climate system in semi-arid and arid regions of the tropics of the world and it covers more than one-third of the land surface vulnerable to drought and desertification [4]. 
Meteorological drought is defined as the deficiency of precipitation from expected or normal levels over an extended period of time. India Meteorological Department (IMD) defines meteorological drought based on rainfall deficiency on sub-division basis. The meteorological droughts are classified into (a) moderate and (b) severe based on rainfall deficiency, i.e. 26 to $50 \%$ and more than $50 \%$, respectively. It must be considered as specific to a region, since the atmospheric conditions that result in deficiencies of precipitation are highly variable from region to region. India is a home to extraordinary variety of climatic regions, ranging from tropical in the south to temperate and alpine in the Himalayan north. The rainfall over India has large spatial as well as temporal variability. The mean monthly rainfall during July is the highest with about one-fourth of the annual rainfall. Drought is a recurrent feature in India with about $28 \%$ of the geographical area being vulnerable to one or the other type of drought. There is hardly any decade when drought has not occurred at least once in two years in some areas of India. The preparedness and planning to cope with adverse impacts of a drought depends on the information about its areal extent, severity and duration. This information can be used to assess and monitor the drought events to provide information to decision makers about drought characteristics [5].

The Himalayan state of Uttarakhand in India is a disaster prone state with landslides, cloudbursts, and flashfloods being seasonal in nature. About $14 \%$ of the land is under cultivation and about $65 \%$ of the population depends on agriculture for their livelihood. The mean annual rainfall of the state is 1547 $\mathrm{mm}$ and more than $85 \%$ cultivable land is rain-fed. It is thus important to carry out drought studies so that the disaster may be monitored in a systematic manner and remedial measures could be made in time. Thus, there is a need to carry out drought monitoring plan and possible drought mitigation strategy in the region.

Various drought indices have been proposed in past few decades, among them some are region specific having limitations for use in other climatic conditions. These include Palmer drought severity index [6], the Decile Index [7], Bhalme and Mooley Drought Index [8], Surface Water Supply Index [9], Standardized Precipitation Index [10, 11, 12], Effective Drought Index [13], Reconnaissance Drought Index [14], Drought Severity Index [15]. [16] reviewed fourteen accepted drought indices that are used for assessing the severity of meteorological, hydrological and agricultural droughts. However, the Standard Precipitation Index (SPI) as recommended by [17] remains a preferred alternative among the researchers as a result of its simplicity, spatial consistency in interpretation, and probabilistic nature. Prediction of drought is helpful in early warning of drought occurrence and to reduce its impact.

Drought severity may vary from site to site under diverse climatic situation; hence, several applications of drought indices and their comparison are useful for specific regions. Drought identification and characterization in a given region allow water resources development and management for their rational use, particularly in the arid and semi-arid zones. It has been found that SPI is the best tool to monitor meteorological drought in India [18]. The SPI is widely used as a meteorological drought index to identify duration/severity of a drought [19]. [20] evaluated regional meteorological drought characteristics across the Pearl River basin in China by deriving severity-area-frequency curves based on SPI as a drought variable. Several studies were conducted on meteorological drought assessment in various parts of India [21, 22, 23, 24].

This study was conducted to assess the temporal trend in monthly, seasonal and annual rainfall series, and investigation of meteorological drought and wet conditions at four stations, namely Naula, Kedar, Chaukhutia and Mehalchauri, located in the upper Ramganga River catchment in Uttarakhand, India.

\section{Materials and Methods}

\subsection{Study Area and Data Acquisition}

The Ramganga River, one of the major tributaries of the Ganga River basin in northern India, originates in the outer Himalayas in Chamoli district of Uttarakhand and enters the plains near Kalagarh after traversing about $168 \mathrm{~km}$ in the hilly terrain with altitudes varying from $260 \mathrm{~m}$ to $2950 \mathrm{~m}$ above mean sea level. The raingauge stations of upper Ramganga catchment selected for this study are Naula, Kedar, Chaukhutia and Mehalchauri, as shown in Fig. 1. Naula, Kedar and Chaukhutia stations are located in the mid-Himalayan region, while Mehalchauri is located in high-Himalayan region.

The climate of the region varies from Himalayan subtropical to sub-temperate having a temperature 
variation from $30^{\circ} \mathrm{C}$ during summer to the minimum temperature of $-2.9^{\circ} \mathrm{C}$ during winter. Most of the precipitation occurs in the form of rainfall from June 15 to September 15 along with occasional winter rains. The soils of this region are highly coarse textured varying from coarse sand to gritty sandy-loam, stony and highly erodible. The soils are mostly acidic in nature with the $\mathrm{pH}$ varying from 5.5 to 6.7 . The soil depth at higher elevations is up to $22 \mathrm{~cm}$ with gravels and varies from $45 \mathrm{~cm}$ to $67 \mathrm{~cm}$ at middle altitudes and $45 \mathrm{~cm}$ to $135 \mathrm{~cm}$ at lower altitudes. The land-use pattern may be broadly classified as forest, pasture, cultivated and waste lands.

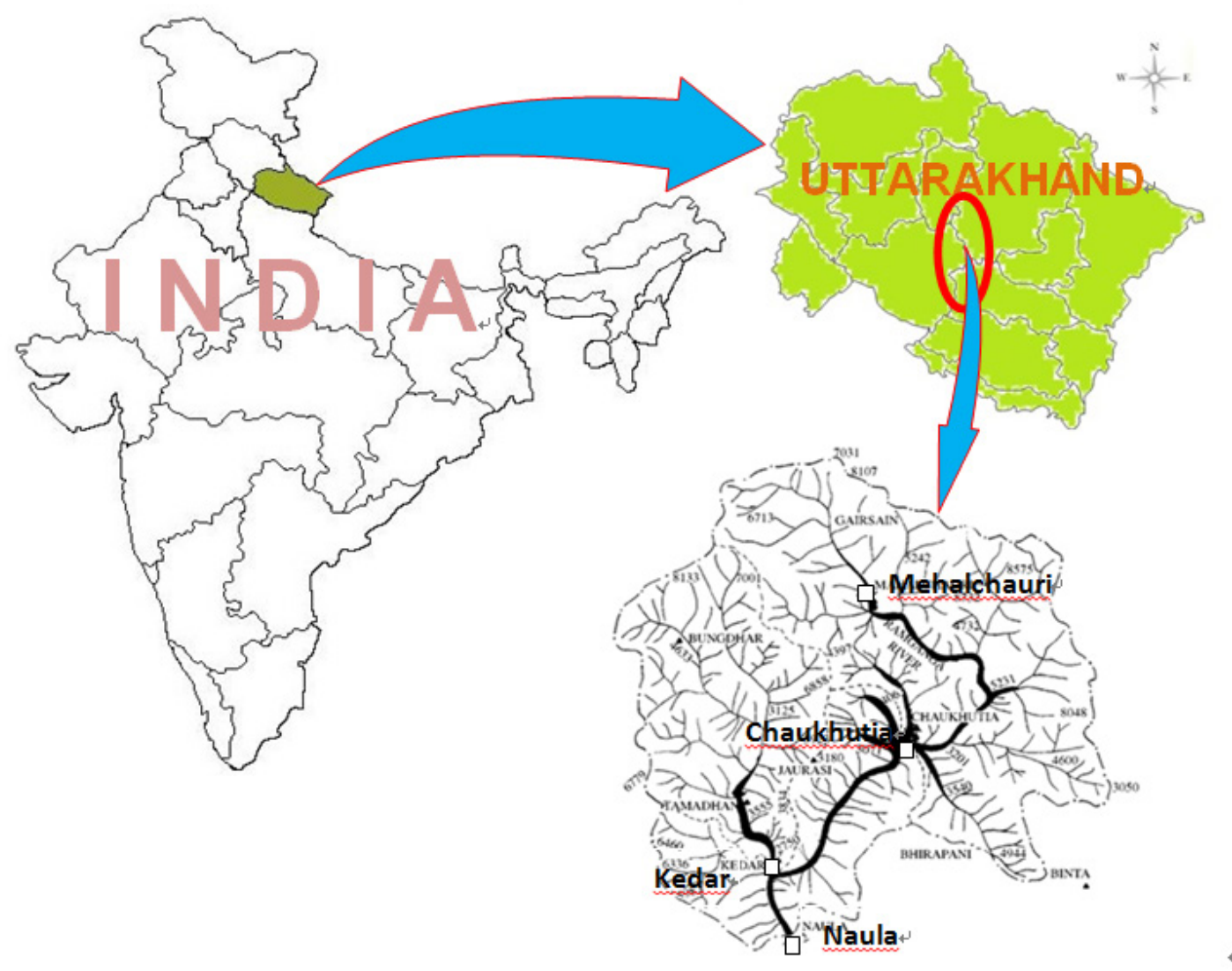

Figure 1. Study area with rain-gauge stations

The daily rainfall data at four stations (Table 1) were collected from the divisional office of the Forest and Soil Conservation Department, Ranikhet, Uttarakhand. Naula and Kedar stations had fairly long years of data, but Chaukhutia and Mahalchauri stations had short term data. The daily data were arranged into monthly, seasonal and annual datasets for detecting the presence of trend and analysis of meteorological drought and wet events.

Table 1. Location coordinates and availability of rainfall data at study stations

\begin{tabular}{|c|c|c|c|c|}
\hline S. No. & Station & Longitude & Latitude & Availability of data (year) \\
\hline 1 & Naula & $70^{\circ} 15^{\prime} 20^{\prime \prime} \mathrm{E}$ & $29^{\circ} 4^{\prime} 20^{\prime \prime \prime} \mathrm{N}$ & 1974 to 2011 \\
\hline 2 & Kedar & $79^{\circ} 14^{\prime} 12^{\prime \prime} \mathrm{E}$ & $29^{\circ} 47^{\prime} 36^{\prime \prime} \mathrm{N}$ & 1974 to 2011 \\
\hline 3 & Chaukhutia & $79^{\circ} 21^{\prime} 50^{\prime \prime} \mathrm{E}$ & $29^{\circ} 53^{\prime} 25^{\prime \prime} \mathrm{N}$ & 1974 to 1995 \\
\hline 4 & Mehalchauri & $79^{\circ} 19^{\prime} 24^{\prime \prime} \mathrm{E}$ & $29^{\circ} 58^{\prime} 12^{\prime \prime} \mathrm{N}$ & 1974 to 1989 \\
\hline
\end{tabular}

\subsection{Trend Analysis}


Testing the significance of observed trends in meteorological time series has received a greater attention recently, especially in connection with the assessment of observed changes in the natural and human environment due to global warming. Long term trend in observed rainfall time-series was analyzed on monthly, seasonal and annual basis. The existence or lack of trend was determined by the statistical tests and further rated as highly significant, significant and moderately significant at $0.01,0.05$ and 0.10 levels of significance, respectively. Determination of trends, its magnitude and statistical significance for all the stations was done by using non-parametric methods. Mann-Kendall trend test (Kendall, 1975), a non-parametric test which does not affect the results with outliers data, was used to identify the trend in a time series even if there is a seasonal component in the series. To analyze the magnitude of trend in the series, a non-parametric Sen's slope method [25] was used to quantitatively determine the rise or fall of the variable per unit of time.

Mann-Kendall Test

The Mann-Kendall (M-K) trend test is a rank correlated test between the rank of observations and their time order (Kendall, 1975). This method has been widely used to test randomness against trend detection in a time series. In this test, the null hypothesis $\left(\mathrm{H}_{0}\right)$ of no trend, i.e., the observations are randomly ordered in time, against the alternative hypothesis $\left(\mathrm{H}_{1}\right)$ with increasing or decreasing monotonic trend detection. The M-K test statistic $\mathrm{S}$ is calculated using the formula:

$$
S=\sum_{i=1}^{n-1} \sum_{j=i+1}^{n} \operatorname{sgn}\left(x_{j}-x_{i}\right)
$$

where, $x_{i}$ is the data time series ranked from $i=1,2, \ldots n-1$; and $j=2,3 \ldots n$. Each of the data point $x_{i}$ is taken as reference point, which is compared with the rest of the data points, $\mathrm{x}_{\mathrm{j}}$ :

$$
\operatorname{sgn}\left(x_{j}-x_{i}\right)=\left\{\begin{array}{cl}
-1 & \text { for } x_{j}<x_{i} \\
0 & \text { for } x_{j}=x_{i} \\
1 & \text { for } x_{j}>x_{i}
\end{array}\right\}
$$

A positive value of $\mathrm{S}$ indicates increasing trend, and a negative value indicates decreasing trend. It has been documented that when $n \geqslant 8$, the statistic $S$ is approximately normally distributed with the mean zero and variance computed as:

$$
\operatorname{Var}(S)=\frac{n(n-1)(2 n+5)-\sum_{i=1}^{m} t_{i}\left(t_{i}-1\right)\left(2 t_{i}+5\right)}{18}
$$

where, $\mathrm{m}$ is the number of tied groups and $\mathrm{t}_{\mathrm{i}}$ is the number of ties in sample $\mathrm{i}$. The normal test statistic $\mathrm{Z}_{\mathrm{MK}}$ is computed as:

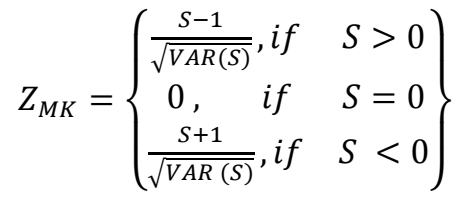

The trend is said to be increasing, if $\mathrm{Z}_{\mathrm{MK}}$ is positive and computed $\mathrm{Z}_{\mathrm{MK}}$ statistic is greater than the $\mathrm{Z}_{\mathrm{MK}}$ value corresponding to a desired level of significance $(0.01,0.05$ or 0.10$)$; and the trend is said to be decreasing, if $\mathrm{Z}_{\mathrm{MK}}$ is negative and computed $\mathrm{Z}_{\mathrm{MK}}$ statistic is greater than the $\mathrm{Z}_{\mathrm{MK}}$ value corresponding to desired level of significance. The null hypothesis $\mathrm{H}_{0}$ representing that no significant trend is present is accepted, if $\mathrm{Z}_{\mathrm{MK}}$ is less than the $\mathrm{Z}_{\mathrm{MK}}$ value.

Sen's slope estimator test

The Sen's slope estimator has been found to be a better and more power tool as compared to simple linear regression to detect the linear trend as it is unaffected by gross data errors and outliers. The Sen's slope is estimated as the median of all pair-wise slopes between each pair of points in the data set. The pair-wise slope $\mathrm{T}_{\mathrm{i}}$ of all data points is computed as:

$$
T_{i j}=\frac{x_{j}-x_{i}}{j-i}
$$

where, $x_{j}$ and $x_{j}$ are data values at the times $i$ and $j(j>i)$, respectively. For $n$ values in data set, there will be $N=n(n-1) / 2$ number of slope estimates, and the median of these $N$ values of $T_{i j}$ is represented as Sen's estimator of slope $\left(Q_{\mathrm{i}}\right)$, which is calculated as:

and,

$$
\mathrm{Q}_{\mathrm{i}}=\mathrm{T}_{(\mathrm{N}+1) / 2} \text {, if } \mathrm{N} \text { is odd }
$$

$$
\mathrm{Q}_{\mathrm{i}}=1 / 2\left(\mathrm{~T}_{\mathrm{N} / 2}+\mathrm{T}_{(\mathrm{N}+2) / 2}\right) \text {, if } \mathrm{N} \text { is even }
$$

Positive value of $\mathrm{Q}_{\mathrm{i}}$ indicates an increasing trend, while a negative value indicates a decreasing trend. 


\subsection{Standardized Precipitation Index (SPI)}

Among various drought indices, SPI [26] is a probability index that considers only rainfall and requires long-term rainfall record for a desired period. Mathematically, it is based on the cumulative probability and the index is negative for drought and positive for wet condition. Due to its statistical consistency and intrinsic probabilistic nature, it describes the impact of both short-term and long-term drought. The SPI was used for temporal drought and wet analysis, to calculate drought severity and probability of occurrence of drought and wet condition as well as for analyzing fluctuation of rainfall pattern using monthly rainfall on multiple time-scales (1-, 3-, 6-, 9-, 12- and 24-months). Computation of the SPI values involves fitting a Gamma probability density function to a given time series of rainfall, whose probability density function is given as:

$$
g(x)=\frac{1}{\beta^{\alpha} \Gamma(\alpha)} x^{\alpha-1} e^{-x / \beta} \text { for } \mathrm{x}>0
$$

where, $\alpha$ is a shape parameter, $\alpha>0 ; \beta$ is a scale parameter, $\beta>0$; $\mathrm{x}$ is the amount of rainfall, $\mathrm{X}>0$; $\Gamma(\alpha)$ is the gamma function of $\alpha$, expressed as $\int_{0}^{\infty} y^{\alpha-1} d y$. The cumulative probability is given as:

$$
G(x)=\frac{1}{\Gamma(\alpha)} \int_{0}^{x} t^{\alpha-1} e^{-t} d t
$$

As the Gamma distribution tends towards the normal as the shape parameter $\alpha$ tends to infinity, it is possible to use the normal probability distribution instead of Gamma, which is computationally easier and may be more accurate due of better fitting to the data. In this case, the SPI index is computed as:

$$
S P I=(Z)=\frac{(x-\mu)}{\sigma}
$$

where, $\mu$ and $\sigma$ are the sample estimates of the population mean and standard deviation, respectively. On the basis of SPI values the wet and drought conditions existing at a place are categorized as presented in Table 2. Some researchers have classified the SPI values falling within \pm 0.99 as near normal which indicates threshold values for drought $(-0.99)$ and wet $(+0.99)$ conditions [27].

Table 2. Classification of drought and wet conditions based on SPI value

\begin{tabular}{lll}
\hline SPI Value & Category & Symbol \\
\hline SPI $\geqslant 2$ & Extremely wet & $\mathrm{D}$ \\
$1.50 \leqslant \mathrm{SPI} \leqslant 1.99$ & Severely wet & $\mathrm{C}$ \\
$1.00 \leqslant \mathrm{SPI} \leqslant 1.49$ & Moderately wet & $\mathrm{B}$ \\
$0.00 \leqslant \mathrm{SPI} \leqslant 0.99$ & Mildly wet & $\mathrm{A}$ \\
$-0.99 \leqslant \mathrm{SPI} \leqslant 0$ & Mildly drought & 1 \\
$-1.49 \leqslant \mathrm{SPI} \leqslant-1.00$ & Moderately drought & 2 \\
$-1.99 \leqslant \mathrm{SPI} \leqslant-1.50$ & Severely drought & 3 \\
$\mathrm{SPI} \leqslant-2$ & Extremely drought & 4 \\
\hline
\end{tabular}

The SPI is computed by fitting a probability density function to the frequency distribution of rainfall summed over the time-scale of interest separately for each month. Each probability density function is then transformed into standardized normal distribution.

\section{Results and Discussion}

The statistical characteristics of monthly, seasonal and annual rainfall at Naula and Kedar, and Chaukhutia and Mehalchauri stations are given in Tables 3 and 4, respectively. The seasonal data were categorized as pre-monsoon season (February to May), monsoon season (June to September) and Postmonsoon (October to January). Statistical characteristics of the rainfall data series are better understood in terms of mean, standard deviation, skewness and kurtosis. Data with skewness close to zero indicate standard normal distribution, and with more positive (negative) values indicate positively (negatively) skewed distribution which explains that the data have mode $<$ median $<$ mean (mode $>$ median $>$ mean). Kurtosis indicates peakedness in the data such that the data with kurtosis equal to zero (meso-kurtic) follow standard normal distribution, while positive (negative) kurtosis indicates more peak or lepto-kurtic (flatness or platy-kurtic) nature. Station-wise statistical characteristics of rainfall pattern is described as follows. 


\subsection{Rainfall Pattern at Naula}

The mean monthly rainfall of 444 months (1974-2011) at Naula station (Table 3) varied from the maximum of $184.33 \mathrm{~mm}$ (August) to the minimum of $7.07 \mathrm{~mm}$ (November). The monthly rainfall ranges from the minimum of zero (October to June) to the maximum of $507.10 \mathrm{~mm}$ (September). The standard deviation (SD), skewness and kurtosis ranged from $13.44 \mathrm{~mm}$ (November) to $107.95 \mathrm{~mm}$ (September), 0.33 (May) to 3.40 (April), and -0.61 (May) to 15.63 (April), respectively. On seasonal basis, the premonsoon season had the mean rainfall as $198.11 \mathrm{~mm}$ with the maximum as $418.9 \mathrm{~mm}$ (1982) and minimum as $30.20 \mathrm{~mm}$ (1998) having the SD, skewness and kurtosis as $86.31 \mathrm{~mm}, 0.55$ and -0.17 , respectively. The monsoon season had the mean rainfall as $563.06 \mathrm{~mm}$ with the maximum as 1194.73 $\mathrm{mm}$ (2009) and minimum as $301.6 \mathrm{~mm}$ (1980) having the SD, skewness and kurtosis as $207.06 \mathrm{~mm}, 1.17$ and 1.18, respectively. The post-monsoon season had the mean rainfall as $92.53 \mathrm{~mm}$ with the maximum as $316.24 \mathrm{~mm}$ (1984) and minimum as $6.0 \mathrm{~mm}$ (2011) having the SD, skewness and kurtosis as 71.66 $\mathrm{mm}, 1.23$ and 1.69, respectively. The mean annual rainfall was $853.70 \mathrm{~mm}$ with the maximum of 1511.73 $\mathrm{mm}$ (1982) and the minimum of $134.80 \mathrm{~mm}$ (2011) having the SD, skewness and kurtosis as $270.16 \mathrm{~mm}$, 0.48 and 0.97 , respectively. The data generally showed positive skewness and lepto-kurtic nature of data (except for January, May, July, and pre-monsoon). The distribution of mean annual rainfall was during pre-monsoon $(23.2 \%)$, monsoon $(65.96 \%)$, and the post-monsoon $(10.84 \%)$.

Table 3. Statistical characteristics of monthly, seasonal and annual rainfall data (1974-2011) at Naula and Kedar stations

\begin{tabular}{|c|c|c|c|c|c|c|c|c|c|c|c|c|}
\hline \multirow{2}{*}{$\begin{array}{l}\text { Month/ } \\
\text { Season/ } \\
\text { Annual }\end{array}$} & \multicolumn{6}{|c|}{ Statistics of rainfall series at Naula } & \multicolumn{6}{|c|}{ Statistics of rainfall series at Kedar } \\
\hline & $\begin{array}{l}\text { Mean } \\
(\mathrm{mm})\end{array}$ & $\begin{array}{l}\text { Max. } \\
(\mathrm{mm})\end{array}$ & $\begin{array}{l}\text { Min. } \\
(\mathrm{mm})\end{array}$ & $\begin{array}{l}\text { SD } \\
(\mathrm{mm})\end{array}$ & Skew. & Kurt. & $\begin{array}{l}\text { Mean } \\
(\mathrm{mm})\end{array}$ & $\begin{array}{l}\text { Max. } \\
(\mathrm{mm})\end{array}$ & $\begin{array}{l}\text { Min. } \\
(\mathrm{mm})\end{array}$ & $\begin{array}{l}\text { SD } \\
(\mathrm{mm})\end{array}$ & Skew. & Kurt. \\
\hline January & 43.74 & 139.90 & 0.00 & 39.84 & 0.72 & -0.58 & 37.62 & 139.20 & 0.00 & 34.58 & 1.06 & 0.60 \\
\hline February & 60.20 & 179.84 & 0.00 & 49.45 & 0.81 & 0.07 & 63.09 & 330.80 & 0.00 & 62.25 & 2.34 & 8.59 \\
\hline March & 48.31 & 181.80 & 0.00 & 46.25 & 1.13 & 0.83 & 46.79 & 162.02 & 0.00 & 45.79 & 1.10 & 0.39 \\
\hline April & 38.29 & 237.00 & 0.00 & 40.76 & 3.40 & 15.63 & 30.97 & 158.94 & 0.00 & 30.12 & 2.41 & 8.38 \\
\hline May & 51.31 & 126.60 & 0.00 & 32.77 & 0.33 & -0.61 & 46.42 & 149.30 & 0.00 & 31.62 & 0.91 & 1.65 \\
\hline June & 99.94 & 301.80 & 0.00 & 63.62 & 1.00 & 1.68 & 102.08 & 234.40 & 0.00 & 61.45 & 0.41 & -0.67 \\
\hline July & 170.82 & 383.20 & 43.00 & 90.08 & 0.79 & -0.06 & 192.70 & 543.00 & 16.51 & 122.97 & 1.33 & 1.46 \\
\hline August & 184.33 & 418.00 & 40.20 & 85.15 & 0.37 & 0.05 & 189.70 & 521.30 & 12.32 & 115.52 & 0.94 & 1.03 \\
\hline September & 107.97 & 507.10 & 1.00 & 107.95 & 2.12 & 5.47 & 116.51 & 429.80 & 2.85 & 95.51 & 1.38 & 2.28 \\
\hline October & 21.78 & 200.20 & 0.00 & 44.03 & 3.11 & 9.97 & 21.45 & 178.00 & 0.00 & 39.54 & 3.13 & 10.23 \\
\hline November & 7.07 & 55.00 & 0.00 & 13.44 & 2.37 & 5.28 & 7.82 & 59.69 & 0.00 & 15.56 & 2.28 & 4.69 \\
\hline December & 19.94 & 114.30 & 0.00 & 29.12 & 1.81 & 2.68 & 14.71 & 85.59 & 0.00 & 19.82 & 1.84 & 3.84 \\
\hline Pre-Mon. & 198.11 & 418.90 & 30.20 & 86.31 & 0.55 & -0.17 & 187.27 & 534.20 & 22.86 & 103.34 & 1.28 & 2.37 \\
\hline Monsoon & 563.06 & 1194.73 & 301.60 & 207.06 & 1.17 & 1.18 & 600.99 & 1424.10 & 247.62 & 265.10 & 1.43 & 2.07 \\
\hline Post-Mon. & 92.53 & 316.24 & 6.00 & 71.66 & 1.23 & 1.69 & 81.60 & 248.84 & 7.62 & 62.55 & 1.17 & 0.69 \\
\hline Annual & 853.70 & 1511.73 & 134.80 & 270.16 & 0.48 & 0.97 & 869.86 & 2089.30 & 121.92 & 359.92 & 1.23 & 2.99 \\
\hline
\end{tabular}

\subsection{Rainfall Pattern at Kedar}

The mean monthly rainfall of 444 months (1974-2011) at Kedar station (Table 3) varied from the minimum of $7.82 \mathrm{~mm}$ (November) to the maximum of $192.70 \mathrm{~mm}$ (July). The monthly rainfall varied from zero (October to May) to $543 \mathrm{~mm}$ (July). The SD, skewness and kurtosis varied from $15.56 \mathrm{~mm}$ (November) to $122.97 \mathrm{~mm}$ (July), 0.41 (June) to 3.13 (October) and -0.67(June) to 10.23 (October), respectively. On seasonal basis, the pre-monsoon season had the mean rainfall as $187.27 \mathrm{~mm}$ with the maximum as $534.20 \mathrm{~mm}$ (1989) and minimum as $22.86 \mathrm{~mm}$ (1998) having the SD, skewness and kurtosis as $103.34 \mathrm{~mm}, 1.28$ and 2.37, respectively. The monsoon season had the mean rainfall as $600.99 \mathrm{~mm}$ with the maximum as $1424.10 \mathrm{~mm}$ (1989) and minimum as $247.62 \mathrm{~mm}$ (1985) having the SD, skewness and kurtosis as $265.10 \mathrm{~mm}, 1.43$ and 2.07, respectively. The post-monsoon season had the mean rainfall as $81.60 \mathrm{~mm}$ with the maximum as $248.84 \mathrm{~mm}$ (1984) and minimum as $7.62 \mathrm{~mm}$ (2011) having the SD, 
skewness and kurtosis as $62.55 \mathrm{~mm}, 1.17$ and 0.69 , respectively. The mean annual rainfall was 869.86 $\mathrm{mm}$ with the maximum of $2098.30 \mathrm{~mm}$ (1989) and the minimum of $121.92 \mathrm{~mm}$ (2011) having the SD, skewness and kurtosis as $359.92 \mathrm{~mm}, 1.23$ and 2.99, respectively. The data generally showed positive skewness and lepto-kurtic nature of data (except for June). The distribution of mean annual rainfall was during pre-monsoon (21.53\%), monsoon (69.09\%), and post-monsoon (9.38\%).

\subsection{Rainfall Pattern at Chaukhutia}

The mean monthly rainfall of 259 months (1974-1995) at Chaukhutia station (Table 4) varied from $8.92 \mathrm{~mm}$ (November) to $337.57 \mathrm{~mm}$ (August). The monthly rainfall varied from zero (October to April) to 607.70 $\mathrm{mm}$ (July). The SD, skewness and kurtosis ranged from $14.92 \mathrm{~mm}$ (November) to $160.48 \mathrm{~mm}$ (August), -0.18 (August) to 2.81 (October) and -1.02 (January) to 9.30 (October). On seasonal basis, the premonsoon season had the mean rainfall as $217.03 \mathrm{~mm}$ with the maximum as $421.10 \mathrm{~mm}$ (1981) and minimum as $88.92 \mathrm{~mm}$ (1988) having the SD, skewness and kurtosis as $94.69 \mathrm{~mm}, 0.62$ and -0.48 , respectively. The monsoon season had the mean rainfall as $942.23 \mathrm{~mm}$ with the maximum as 1455.10 $\mathrm{mm}$ (1979) and minimum as $226.10 \mathrm{~mm}$ (1993) having the SD, skewness and kurtosis as $333.82 \mathrm{~mm},-$ 0.48 and -0.59 , respectively. Post-monsoon period had the mean rainfall as $113.63 \mathrm{~mm}$ with the maximum as $340.20 \mathrm{~mm}$ (1984) and minimum as $3.50 \mathrm{~mm}$ (1974) having the SD, skewness and kurtosis as $79.37 \mathrm{~mm}, 1.05$ and 1.77, respectively. The annual rainfall was $1272.89 \mathrm{~mm}$ with the maximum of $1920.70 \mathrm{~mm}$ (1981) and the minimum of $379.40 \mathrm{~mm}$ (1998) having the SD, skewness and kurtosis as $421.96 \mathrm{~mm},-0.23$ and -0.55 , respectively. The data generally showed positive skewness (except for August, Monsoon and annual) and lepto-kurtic nature of data (except for January, February, May, July, August, pre-monsoon, monsoon and annual). The distribution of the mean annual rainfall was during pre-monsoon $(17.05 \%)$, monsoon $(74.02 \%)$, and post-monsoon $(8.93 \%)$.

Table 4. Statistical characteristics of monthly, seasonal and annual rainfall (1974-1995) at Chaukhutia and Mehalchauri stations

\begin{tabular}{|c|c|c|c|c|c|c|c|c|c|c|c|c|}
\hline \multirow{2}{*}{$\begin{array}{l}\text { Month/ } \\
\text { Season/ } \\
\text { Annual }\end{array}$} & \multicolumn{6}{|c|}{ Statistics of rainfall series at Chaukhutia } & \multicolumn{6}{|c|}{ Statistics of rainfall series at Mehalchauri } \\
\hline & $\begin{array}{l}\text { Mean } \\
(\mathrm{mm})\end{array}$ & $\begin{array}{l}\text { Max. } \\
(\mathrm{mm})\end{array}$ & $\begin{array}{l}\text { Min. } \\
(\mathrm{mm})\end{array}$ & $\begin{array}{l}\text { SD } \\
(\mathrm{mm})\end{array}$ & Skew. & Kurt. & $\begin{array}{l}\text { Mean } \\
(\mathrm{mm}) \\
\end{array}$ & $\begin{array}{l}\text { Max. } \\
(\mathrm{mm})\end{array}$ & $\begin{array}{l}\text { Min. } \\
(\mathrm{mm})\end{array}$ & $\begin{array}{l}\text { SD } \\
(\mathrm{mm})\end{array}$ & Skew. & Kurt. \\
\hline January & 49.49 & 129.80 & 0.00 & 39.77 & 0.38 & -1.02 & 42.51 & 108.50 & 0.00 & 37.46 & 0.43 & -1.02 \\
\hline February & 55.41 & 127.20 & 0.00 & 33.29 & 0.14 & -0.12 & 58.86 & 147.00 & 4.70 & 41.76 & 0.61 & -0.20 \\
\hline March & 57.51 & 197.50 & 0.00 & 52.99 & 1.14 & 0.96 & 60.09 & 215.90 & 0.00 & 57.02 & 1.55 & 2.95 \\
\hline April & 44.45 & 151.00 & 0.00 & 37.40 & 1.24 & 1.70 & 46.74 & 159.00 & 0.00 & 43.52 & 1.53 & 2.14 \\
\hline May & 59.66 & 161.90 & 6.50 & 46.63 & 0.96 & -0.06 & 86.22 & 214.00 & 2.50 & 62.19 & 0.59 & -0.29 \\
\hline June & 158.51 & 522.60 & 35.80 & 102.62 & 2.18 & 6.98 & 142.23 & 322.70 & 16.00 & 78.72 & 0.85 & 0.69 \\
\hline July & 287.28 & 607.70 & 63.80 & 156.72 & 0.25 & -0.99 & 285.54 & 580.70 & 122.00 & 132.19 & 0.73 & -0.12 \\
\hline August & 337.57 & 596.90 & 38.60 & 160.48 & -0.18 & -0.83 & 269.27 & 582.21 & 79.00 & 141.52 & 0.67 & -0.05 \\
\hline September & 158.87 & 412.50 & 18.90 & 102.35 & 0.96 & 0.97 & 127.50 & 275.40 & 4.00 & 82.35 & 0.27 & -0.94 \\
\hline October & 22.38 & 159.40 & 0.00 & 36.62 & 2.81 & 9.30 & 25.73 & 143.00 & 0.00 & 38.30 & 2.20 & 5.40 \\
\hline November & 8.92 & 53.40 & 0.00 & 14.92 & 1.72 & 2.48 & 12.30 & 58.82 & 0.00 & 17.96 & 1.63 & 2.09 \\
\hline December & 32.84 & 111.00 & 0.00 & 33.42 & 1.03 & 0.37 & 35.97 & 112.00 & 0.00 & 32.32 & 1.00 & 0.40 \\
\hline Pre-Mon. & 217.03 & 421.10 & 88.92 & 94.69 & 0.62 & -0.48 & 251.91 & 462.00 & 25.50 & 99.63 & -0.40 & 1.94 \\
\hline Monsoon & 942.23 & 1455.10 & 226.10 & 333.82 & -0.48 & -0.59 & 824.54 & 1450.70 & 364.00 & 316.67 & 0.82 & 0.03 \\
\hline Post-Mon. & 113.63 & 340.20 & 3.50 & 79.37 & 1.05 & 1.77 & 116.51 & 318.50 & 10.00 & 78.48 & 0.93 & 1.76 \\
\hline Annual & 1272.89 & 1920.70 & 379.40 & 421.96 & -0.23 & -0.55 & 1192.96 & 1875.30 & 681.91 & 365.32 & 0.67 & -0.18 \\
\hline
\end{tabular}

\subsection{Rainfall Pattern at Mehalchauri}

The mean monthly rainfall of 187 months (1974-1989) at Mehalchauri station (Table 4) varied from $12.30 \mathrm{~mm}$ (November) to $285.54 \mathrm{~mm}$ (July). The monthly rainfall varies from zero (October to January) to $582.21 \mathrm{~mm}$ (August). The SD, skewness and kurtosis varied from $17.96 \mathrm{~mm}$ (November) to 141.52 mm (August), 0.27 (September) to 2.20 (October) and -1.02 (January) to 5.40 (October). On seasonal 
basis, the pre-monsoon season had the mean rainfall as $251.91 \mathrm{~mm}$ with the maximum as $462.0 \mathrm{~mm}$ (1982) and minimum as $25.50 \mathrm{~mm}$ (1988) having the SD, skewness and kurtosis as $99.63 \mathrm{~mm},-0.40$ and 1.94, respectively. The monsoon season had the mean rainfall as $824.54 \mathrm{~mm}$ with the maximum as $1450.70 \mathrm{~mm}$ (1977) and the minimum as $364.0 \mathrm{~mm}$ (1986) having the SD, skewness and kurtosis as $316.67 \mathrm{~mm}, 0.82$ and 0.03 , respectively. The post-monsoon season had the mean rainfall as $113.86 \mathrm{~mm}$ with the maximum as $318.50 \mathrm{~mm}$ (1984) and minimum as $10.00 \mathrm{~mm}$ (1974) having the SD, skewness and kurtosis as $78.48 \mathrm{~mm}, 0.93$ and 1.76, respectively. The mean annual rainfall was $1174.57 \mathrm{~mm}$ with the maximum of $1875.30 \mathrm{~mm}$ (1977) and the minimum of $681.91 \mathrm{~mm}$ (1986) having the SD, skewness and kurtosis as $365.32 \mathrm{~mm}, 0.67$ and -0.18 , respectively. The data generally showed positive skewness (except for pre-monsoon) and lepto-kurtic nature of data (except for January, February, May, July, August, September and annual). The distribution of mean annual rainfall was during the pre-monsoon $(21.11 \%)$, monsoon $(69.12 \%)$, and post-monsoon $(9.77 \%)$.

\subsection{Rainfall Trend Analysis}

The existence of trend in rainfall data series of all months, seasons and annual for Naula, Kedar, Chaukhutia and Mehalchauri stations were computed. The Mann-Kendall test statistic $\left(\mathrm{Z}_{\mathrm{MK}}\right)$ and Sen's slope estimator $(\mathrm{Q})$ were used to identify the nature and magnitude of trend, respectively in the rainfall data series corresponding to various levels of significance for all stations (Table 5). Positive value of $Z_{M K}$ and $\mathrm{Q}$ indicates an increasing trend and negative value indicates a decreasing trend. Station-wise analysis of trend in rainfall data series is given as follows.

Table 5. Mann-Kendall test statistic $\left(\mathrm{Z}_{\mathrm{MK}}\right)$ and Sen's slope estimator (Q) for monthly, seasonal and annual rainfall data series for all stations

\begin{tabular}{|c|c|c|c|c|c|c|c|c|}
\hline \multirow[t]{2}{*}{ Period } & \multicolumn{2}{|l|}{ Naula } & \multicolumn{2}{|l|}{ Kedar } & \multicolumn{2}{|c|}{ Chaukhutia } & \multicolumn{2}{|c|}{ Mehalchauri } \\
\hline & $\mathrm{Z}_{\mathrm{MK}}$ & $\mathrm{Q}$ & $\mathrm{Z}_{\mathrm{MK}}$ & $\mathrm{Q}$ & $\mathrm{Z}_{\mathrm{MK}}$ & $\mathrm{Q}$ & $\mathrm{Z}_{\mathrm{MK}}$ & $\mathrm{Q}$ \\
\hline January & -1.0316 & -0.4087 & -0.8305 & -0.3233 & 0.7357 & 1.0440 & 0.3638 & 2.2240 \\
\hline February & 0.7168 & 0.4000 & 1.0064 & 0.7000 & 0.9595 & 1.0360 & 1.1256 & 0.3667 \\
\hline March & -1.0819 & -0.4294 & -0.3398 & -0.1271 & 0.3667 & 0.2727 & -0.2704 & 3.0000 \\
\hline April & 0.8426 & 0.2844 & 0.8804 & 0.2822 & -1.2430 & -0.5000 & -0.9915 & -1.1470 \\
\hline May & -0.3143 & -0.2500 & -0.3774 & -0.1786 & -0.3384 & -0.4909 & -0.4052 & -1.7400 \\
\hline June & 0.6035 & 0.4688 & -0.5407 & -0.5173 & $-2.0303^{* *}$ & -5.0270 & -1.1256 & -4.7870 \\
\hline July & -1.5081 & -2.1000 & $-2.3763^{*}$ & -3.1040 & $-2.8198^{*}$ & -14.740 & -0.3152 & -4.5540 \\
\hline August & -0.0754 & -0.0714 & -1.1819 & -2.1170 & $-1.9739 * *$ & -13.560 & -1.2156 & -13.610 \\
\hline September & $1.6598^{* * *}$ & 2.1510 & 0.7293 & 1.0230 & -1.0151 & -3.7500 & -0.6753 & -4.5310 \\
\hline October & 0.0775 & 0.0000 & 0.1048 & 0.0000 & -1.6364 & -0.5905 & -0.3180 & -0.0962 \\
\hline November & -1.1377 & 0.0000 & -0.8008 & 0.0000 & -0.8662 & 0.0000 & 0.2417 & 0.0000 \\
\hline December & $-2.5573^{*}$ & -0.4577 & $-2.3775^{*}$ & -0.2489 & -0.3961 & -0.3000 & 1.4857 & 2.2240 \\
\hline Pre-monsoon & -0.5281 & -0.7837 & -0.3018 & -0.3877 & -0.7332 & -2.3750 & -0.8554 & -5.1790 \\
\hline Monsoon & 1.1310 & 2.9290 & -1.2075 & -4.0690 & $-2.9326^{*}$ & -35.230 & -0.5853 & -19.060 \\
\hline Post-monsoon & $-2.0368^{* *}$ & -1.7930 & $-1.7225^{* * *}$ & -1.3580 & -0.5076 & -1.7920 & 1.0355 & 4.1440 \\
\hline Annual & 0.5029 & 1.3250 & -0.9560 & -4.3490 & $-2.6506^{*}$ & -34.4100 & -0.7654 & -19.560 \\
\hline
\end{tabular}

Significant at: 0.01 level $(*) ; 0.05$ level $(* *) ;$ and 0.10 level $(* * *)$

Trend analysis for Naula station (Table 5) revealed that there was significantly increasing trend for September at $10 \%$ level of significance, but significantly decreasing trends for December at $1 \%$ level and for post-monsoon season at $5 \%$ level. Rest of the months, seasons and annual data showed nonsignificantly increasing or decreasing trends as indicated by their $\mathrm{Z}_{\mathrm{MK}}$ values.

Trend analysis for Kedar station (Table 5) revealed that there was significantly decreasing trends for July and December at $1 \%$ level, and for post-monsoon season at $10 \%$ level. Rest of the months, seasons and annual data showed non-significantly increasing or decreasing trends.

Trend analysis for Chaukhutia station (Table 5) revealed that there was significantly decreasing trends for July, monsoon season and annual data series at 1\% level and for June and August at 5\% level. 
Rest of the months, seasons and annual data showed non-significantly increasing or decreasing trends. This indicates that the rainfall pattern at Chaukhutia station, which is located in mid-Himalayan region, is having a declining trend.

Trend analysis for Mahalchauri station (Table 5) revealed no trend even at $10 \%$ level of significance; however, the monthly, seasonal and annual data series showed non-significantly increasing or decreasing trends. This indicates that the rainfall pattern at Mehalchauri, which is located in upper-Himalayan region, is having no trend affected much by climate change.

\subsection{Drought and Wet Analysis}

The SPI was used to assess the meteorological drought and wet conditions on multi-temporal time-scales (1-, 3-, 6-, 9-, 12-, and 24-months) for Naula, Kedar, Chaukhutia and Mehalchauri stations under study. Station-wise results of the occurrence of drought and wet spells are described as follows.

Drought and Wet Pattern at Naula

Table 6(a). SPI-based drought pattern of rainfall series at Naula station

\begin{tabular}{|c|c|c|c|c|c|c|c|}
\hline \multirow{2}{*}{$\begin{array}{l}\text { SPI } \\
\text { category }\end{array}$} & \multirow{2}{*}{$\begin{array}{l}\text { Drought } \\
\text { months }\end{array}$} & \multirow{2}{*}{$\begin{array}{l}\text { Drought } \\
\text { incidents }\end{array}$} & \multirow{2}{*}{$\begin{array}{l}\text { Average } \\
\text { duration } \\
\text { (month) }\end{array}$} & \multicolumn{4}{|c|}{ Longest drought pattern } \\
\hline & & & & $\begin{array}{l}\text { Duration } \\
\text { (month) }\end{array}$ & Period & Severity & $\begin{array}{l}\text { Average } \\
\text { intensity }\end{array}$ \\
\hline SPI-1 & 282 & 91 & 3.1 & 11 & Feb 91 to Dec 91 & -5.646 & -0.513 \\
\hline SPI-3 & 254 & 53 & 4.8 & 13 & $\begin{array}{l}\text { Jan } 98 \text { to Jan } 99 \\
\text { May } 02 \text { to May } 03\end{array}$ & $\begin{array}{l}-11.565 \\
-7.912\end{array}$ & $\begin{array}{l}-0.890 \\
-0.609\end{array}$ \\
\hline SPI-6 & 247 & 36 & 6.9 & 22 & Jul 78 to Apr 80 & -14.061 & -0.639 \\
\hline SPI-9 & 249 & 31 & 8.0 & 33 & Aug 78 to Apr 81 & -27.094 & -0.821 \\
\hline SPI-12 & 263 & 23 & 11.4 & 41 & Aug 78 to Dec 81 & -31.159 & -0.760 \\
\hline SPI-24 & 268 & 21 & 12.8 & 72 & Jul 99 to Jun 05 & -44.220 & -0.614 \\
\hline
\end{tabular}

Table 6(b). SPI-based wet pattern of rainfall series at Naula station

\begin{tabular}{|c|c|c|c|c|c|c|c|}
\hline \multirow{2}{*}{$\begin{array}{l}\text { SPI } \\
\text { category }\end{array}$} & \multirow{2}{*}{$\begin{array}{l}\text { Wet } \\
\text { months }\end{array}$} & \multirow{2}{*}{$\begin{array}{l}\text { Wet } \\
\text { incidents }\end{array}$} & \multirow{2}{*}{$\begin{array}{l}\text { Average } \\
\text { duration } \\
\text { (month) }\end{array}$} & \multicolumn{4}{|c|}{ Longest wet pattern } \\
\hline & & & & $\begin{array}{l}\text { Duration } \\
\text { (month) }\end{array}$ & Period & Severity & $\begin{array}{l}\text { Average } \\
\text { intensity }\end{array}$ \\
\hline SPI-1 & 162 & 91 & 1.8 & 7 & Mar 82 to Sep 82 & 9.807 & 1.401 \\
\hline SPI-3 & 188 & 53 & 3.6 & 15 & Oct 96 to Dec 97 & 17.933 & 1.196 \\
\hline SPI-6 & 192 & 36 & 5.3 & 20 & Aug 96 to Mar 98 & 20.953 & 1.048 \\
\hline SPI-9 & 186 & 31 & 6.0 & 26 & Apr 92 to Apr 94 & 37.322 & 1.435 \\
\hline SPI-12 & 170 & 23 & 7.4 & 28 & Mar 92 to Jun 94 & 41.194 & 1.471 \\
\hline SPI-24 & 153 & 21 & 7.3 & 23 & Jun 93 to Apr 95 & 43.538 & 1.893 \\
\hline
\end{tabular}

General pattern of drought and wet events for Naula station is given in Tables 6(a) and 6(b), respectively. It is evident from Table 6(a) that the total number of drought months reduced from 282 (SPI-1) to 247 (SPI-6), but increased to 268 (SPI-24). The number of drought incidents continuously decreased from 91 (SPI-1) to 21 (SPI-24); however, average duration of drought increased from 3.1 months (SPI-1) to 12.8 months (SPI-24). The longest duration of drought severity continuously increased from 11 months (SPI-1) to 72 months (SPI-24); however, its average intensity varied from 0.513 (SPI-1) to -0.890 (SPI-3) which fell under mild drought category. It indicates that mild drought incidents are expected to occur more frequently with short durations rather than that for long durations. It was also revealed that out of 444 months, the extreme drought occurred during 4 months $(0.90 \%)$ only, one each on short term (SPI-3) and long term (SPI-12) basis, and twice on medium term (SPI-9) basis. The most extreme drought occurred in June, 1984 for SPI-12. However, the severe drought occurred during 44 months $(9.9 \%)$ out of 444 months of record at Naula station. All other months had the mild and moderate droughts more frequently. This indicates very low frequency of extreme and severe drought conditions at Naula station. 
Table 6(b) indicates that total number of wet months increased from 162 (SPI-1) to 192 (SPI-6), but decreased from 192 (SPI-6) to 153 (SPI-24). Just like drought events, the number of wet incidents also continuously decreased from 91 (SPI-1) to 21 (SPI-24); however, average duration of wet events increased from 1.8 months (SPI-1) to 7.4 months (SPI-12), but slightly decreased to 7.3 months for SPI-24. The longest duration of wet severity continuously increased from 7 months (SPI-1) to 28 months (SPI-12) and slightly decreased to 23 months (SPI-24); however, average wet intensity varied from 1.048 (SPI-6) to 1.893 (SPI-24) which fell under moderate and severe wet category. It was also revealed that out of 444 months of record, the extreme and severe wet conditions accounted for only 117 months (26.4\%) and 118 months (26.6\%), respectively, indicating no serious threat of drought or drainage problems, however rainwater harvesting should be encouraged in the region.

Drought and Wet Pattern at Kedar

Table 7(a). SPI-based drought pattern of rainfall series at Kedar station

\begin{tabular}{llllllll}
\hline SPI & Drought & Drought & Average & \multicolumn{4}{c}{ Longest drought pattern } \\
\cline { 6 - 8 } category & months & incidents & $\begin{array}{l}\text { duration } \\
\text { (month) }\end{array}$ & $\begin{array}{l}\text { Duration } \\
\text { (month) }\end{array}$ & Period & Severity & $\begin{array}{l}\text { Average } \\
\text { intensity }\end{array}$ \\
\hline SPI-1 & 293 & 84 & 3.5 & 11 & Feb 91 to Dec 91 & -9.054 & -0.823 \\
& & & & 11 & Mar 02 to Mar 03 & -8.808 & -0.801 \\
SPI-3 & 256 & 55 & 4.7 & 15 & Jul 07 to Sep 08 & -12.119 & -0.808 \\
SPI-6 & 251 & 27 & 9.3 & 30 & Aug 06 to Jan 09 & -22.487 & -0.750 \\
SPI-9 & 256 & 27 & 9.5 & 35 & Jun 90 to Apr 93 & -31.296 & -0.894 \\
SPI-12 & 255 & 18 & 14.2 & 48 & Jun 00 to May 04 & -33.676 & -0.702 \\
SPI-24 & 265 & 15 & 17.7 & 69 & Sep 99 to May 05 & -41.739 & -0.605 \\
\hline
\end{tabular}

Table 7(b). SPI-based wet pattern of rainfall series at Kedar station

\begin{tabular}{|c|c|c|c|c|c|c|c|}
\hline \multirow{2}{*}{$\begin{array}{l}\text { SPI } \\
\text { category }\end{array}$} & \multirow{2}{*}{$\begin{array}{l}\text { Wet } \\
\text { months }\end{array}$} & \multirow{2}{*}{$\begin{array}{l}\text { Wet } \\
\text { incidents }\end{array}$} & \multirow{2}{*}{$\begin{array}{l}\text { Average } \\
\text { duration } \\
\text { (month) }\end{array}$} & \multicolumn{4}{|c|}{ Longest wet pattern } \\
\hline & & & & $\begin{array}{l}\text { Duration } \\
\text { (month) }\end{array}$ & Period & Severity & $\begin{array}{l}\text { Average } \\
\text { intensity }\end{array}$ \\
\hline SPI-1 & 151 & 84 & 1.8 & 7 & Feb 87 to Aug 87 & 9.521 & 1.360 \\
\hline SPI-3 & 186 & 54 & 3.4 & 14 & Nov 96 to Dec 97 & 15.145 & 1.082 \\
\hline SPI-6 & 188 & 27 & 7.0 & 46 & May 86 to Feb 90 & 69.158 & 1.503 \\
\hline SPI-9 & 180 & 26 & 6.9 & 24 & Jun 88 to May 90 & 48.692 & 2.029 \\
\hline SPI-12 & 178 & 18 & 9.9 & 48 & Aug 86 to Jul 90 & 86.102 & 1.794 \\
\hline SPI-24 & 157 & 15 & 10.5 & 48 & Jun 87 to Apr 91 & 93.785 & 1.954 \\
\hline
\end{tabular}

The general pattern of drought and wet events for Kedar station is given in Tables $7(\mathrm{a})$ and (b), respectively. It is evident from Table 7(a) that the total number of drought months reduced from 293 (SPI-1) to 251 (SPI-6), but increased from 251 (SPI-6) to 265 (SPI-24). The number of drought incidents continuously decreased from 84 (SPI-1) to 15 (SPI-24); however, average duration of drought increased from 3.5 months (SPI-1) to 17.7 months (SPI-24). The longest duration of drought severity continuously increased from 11 months (SPI-1) to 69 months (SPI-24); however, average intensity varied from -0.894 (SPI-9) to -0.605 (SPI-24) which fell under mild drought category. It indicates that mild drought incidents are expected to occur more frequently with short durations rather than that for long durations. It was also revealed that there were no occurrences of extreme drought during 37 years (444 months) of rainfall data; however, there were only 30 months $(6.8 \%)$ of severe drought.

Table 7(b) indicates that total number of wet months increased from 151 (SPI-1) to 188 (SPI-6), but decreased from 188 (SPI-6) to 157 (SPI-24). Just like drought events, the number of wet incidents also continuously decreased from 84 (SPI-1) to 15 (SPI-24); however, average duration increased from 1.8 (SPI-1) to 10.5 (SPI-24) months. It indicates that the wet incidents occur more 
frequently with short durations rather than that for long durations at Kedar station. The longest duration of wet severity continuously increased from 7 months (SPI-1) to 46 months (SPI-6); decreased to 24 (SPI-9); and increased to 48 (SPI- 12 and 24); however, its average intensity varied from 1.082 (SPI-3) as moderate wet to 2.029 (SPI-9) as extreme wet category. On the other hand, the extreme wet events were $136(30.6 \%)$ and severe wet events were 91 (20.5\%). This reveals that there are nearly $51 \%$ chances of serious wet conditions at Kedar station. Therefore, more efforts will be required to take precautionary measures for the control of floods and water logging in the low-lying areas in valleys along with rainwater harvesting.

Drought and Wet Pattern at Chaukhutia

Table 8(a). SPI-based drought pattern of rainfall series at Chaukhutia station

\begin{tabular}{|c|c|c|c|c|c|c|c|}
\hline \multirow{2}{*}{$\begin{array}{l}\text { SPI } \\
\text { category }\end{array}$} & \multirow{2}{*}{$\begin{array}{l}\text { Drought } \\
\text { months }\end{array}$} & \multirow{2}{*}{$\begin{array}{l}\text { Drought } \\
\text { incidents }\end{array}$} & \multirow{2}{*}{$\begin{array}{l}\text { Average } \\
\text { Duration } \\
\text { (month) }\end{array}$} & \multicolumn{4}{|c|}{ Longest drought pattern } \\
\hline & & & & $\begin{array}{l}\text { Duration } \\
\text { (month) }\end{array}$ & Period & Severity & $\begin{array}{l}\text { Average } \\
\text { intensity }\end{array}$ \\
\hline SPI-1 & 158 & 58 & 2.7 & 23 & Oct 92 to Aug 94 & -20.314 & -0.883 \\
\hline SPI-3 & 136 & 33 & 4.1 & 26 & Dec 92 to Jan 95 & -28.527 & -1.097 \\
\hline SPI-6 & 131 & 25 & 5.2 & 34 & Mar 93 to Dec 95 & -43.390 & -1.276 \\
\hline SPI-9 & 129 & 18 & 7.2 & 31 & Jun 93 to Dec 95 & -45.997 & -1.484 \\
\hline SPI-12 & 129 & 17 & 7.6 & 90 & Jul 88 to Dec 95 & -91.863 & -1.021 \\
\hline SPI-24 & 91 & 4 & 22.8 & 79 & Jun 89 to Dec 95 & -88.890 & -1.125 \\
\hline
\end{tabular}

Table 8(b). SPI-based wet pattern of rainfall series at Chaukhutia station

\begin{tabular}{|c|c|c|c|c|c|c|c|}
\hline \multirow{2}{*}{$\begin{array}{l}\text { SPI } \\
\text { category }\end{array}$} & \multirow{2}{*}{$\begin{array}{l}\text { Wet } \\
\text { months }\end{array}$} & \multirow{2}{*}{$\begin{array}{l}\text { Wet } \\
\text { incidents }\end{array}$} & \multirow{2}{*}{$\begin{array}{l}\text { Average } \\
\text { duration } \\
\text { (month) }\end{array}$} & \multicolumn{4}{|c|}{ Longest wet pattern } \\
\hline & & & & $\begin{array}{l}\text { Duration } \\
\text { (month) }\end{array}$ & Period & Severity & $\begin{array}{l}\text { Average } \\
\text { intensity }\end{array}$ \\
\hline \multirow[t]{6}{*}{ SPI-1 } & 102 & 58 & 1.8 & 4 & Apr 76 to Jul 76 & 7.331 & 1.833 \\
\hline & & & & 4 & Jan 81 to Apr 81 & 4.882 & 1.221 \\
\hline & & & & 4 & Jul 82 to Oct 82 & 4.229 & 1.057 \\
\hline & & & & 4 & Jul 84 to Oct 84 & 5.738 & 1.434 \\
\hline & & & & 4 & May 85 to Aug 85 & 3.516 & 0.879 \\
\hline & & & & 4 & Feb 87 to May 87 & 3.734 & 0.933 \\
\hline SPI-3 & 121 & 33 & 3.7 & 25 & Nov 80 to Nov 82 & 30.793 & 1.232 \\
\hline SPI-6 & 123 & 25 & 4.9 & 27 & Dec 80 to Feb 83 & 36.691 & 1.359 \\
\hline SPI-9 & 122 & 18 & 6.8 & 33 & Feb 81 to Oct 83 & 38.729 & 1.174 \\
\hline SPI-12 & 119 & 17 & 7.0 & 32 & Feb 81 to Sep 83 & 37.845 & 1.183 \\
\hline SPI-24 & 144 & 4 & 36.0 & 110 & Jul 79 to Aug 88 & 79.580 & 0.723 \\
\hline
\end{tabular}

The general pattern of drought and wet events for Chaukhutia station is given in Tables 8(a) and 8(b), respectively. Table 8(a) reveals that the total number of drought months reduced from 158 (SPI-1) to 91 (SPI-24). The number of drought incidents continuously decreased from 58 (SPI-1) to 4 (SPI-24); however, average duration of drought increased from 2.7 (SPI-1) to 22.8 (SPI-24) months. It indicates that mild drought incidents are expected to occur more frequently with short durations rather than that for long durations. The longest duration of drought severity continuously increased from 23 months (SPI-1) to 34 months (SPI-6), but sharply increased from 31 (SPI-9) to 90 (SPI-12) and reduced to 79 (SPI-24); however, average intensity varied from -0.883 (SPI-1) as mild drought to -1.484 (SPI-9) as moderate drought. It was also indicated that out of 259 rainfall data, there were $26(10 \%)$ events of extreme drought mostly at medium and long time scales; however, there were 46 months $(17.8 \%)$ of severe drought and rest were mild and moderate drought. The most extreme drought occurred in May, 1994 for SPI-12.

Table 8(b) indicates that total number of wet months increased from 102 (SPI-1) to 123 (SPI-6), but decreased from 123 (SPI-6) to 119 (SPI-12) and further increased to 144 (SPI-24). Just like drought events, the number of wet incidents also continuously decreased from 58 (SPI-1) to 4 (SPI-24); however, 
average duration increased from 1.8 (SPI-1) to 36.0 (SPI-24) months. The longest duration of wet severity continuously increased from 4 months (SPI-1) to 33 months (SPI-9); decreased to 32 (SPI-12); and sharply increased to 110 (SPI-24); however, its average intensity varied from 1.833 (SPI-1) as severe wet to 0.723 (SPI-24) as mild wet category. Also, the extreme wet events were $24(9.3 \%)$ and severe wet events were 59 (22.8\%). This reveals that there are only $31.4 \%$ chances of serious wet conditions and most of the months had mild and moderate wet conditions at Chaukhutia station. It indicates that the wet incidents occur more frequently with short durations rather than that for long durations at Chaukhutia station. Therefore, more efforts will be required to take precautionary measures for the control of floods and water logging in the valleys along with rainwater harvesting.

Drought and Wet Pattern at Mehalchauri

Table 9(a). SPI-based drought pattern of rainfall series at Mehalchauri station

\begin{tabular}{|c|c|c|c|c|c|c|c|}
\hline \multirow{2}{*}{$\begin{array}{l}\text { SPI } \\
\text { category }\end{array}$} & \multirow{2}{*}{$\begin{array}{l}\text { Drought } \\
\text { months }\end{array}$} & \multirow{2}{*}{$\begin{array}{l}\text { Drought } \\
\text { incidents }\end{array}$} & \multirow{2}{*}{$\begin{array}{l}\text { Average } \\
\text { duration } \\
\text { (month) }\end{array}$} & \multicolumn{4}{|c|}{ Longest drought pattern } \\
\hline & & & & $\begin{array}{l}\text { Duration } \\
\text { (month) }\end{array}$ & Period & Severity & $\begin{array}{l}\text { Average } \\
\text { intensity }\end{array}$ \\
\hline SPI-1 & 117 & 43 & 2.7 & 8 & Jun 86 to Jan 87 & -8.394 & -1.049 \\
\hline SPI-3 & 101 & 27 & 3.7 & 11 & Mar 88 to Jan 89 & -9.920 & -0.902 \\
\hline SPI-6 & 101 & 17 & 5.9 & 19 & Mar 83 to Sep 84 & -13.555 & -0.713 \\
\hline SPI-9 & 104 & 11 & 9.5 & 37 & Jun 86 to Jun 89 & -31.192 & -0.843 \\
\hline SPI-12 & 104 & 7 & 14.9 & 42 & Jun 86 to Nov 89 & -32.845 & -0.782 \\
\hline SPI-24 & 103 & 4 & 25.8 & 43 & Jun86 to Dec89 & -32.322 & -0.752 \\
\hline
\end{tabular}

Table 9(b). SPI-based wet pattern of rainfall series at Mehalchauri station

\begin{tabular}{|c|c|c|c|c|c|c|c|}
\hline \multirow{2}{*}{$\begin{array}{l}\text { SPI } \\
\text { category }\end{array}$} & \multirow{2}{*}{$\begin{array}{l}\text { Wet } \\
\text { months }\end{array}$} & \multirow{2}{*}{$\begin{array}{l}\text { Wet } \\
\text { incidents }\end{array}$} & \multirow{2}{*}{$\begin{array}{l}\text { Average } \\
\text { duration } \\
\text { (month) }\end{array}$} & \multicolumn{4}{|c|}{ Longest wet pattern } \\
\hline & & & & $\begin{array}{l}\text { Duration } \\
\text { (month) }\end{array}$ & Period & Severity & $\begin{array}{l}\text { Average } \\
\text { intensity }\end{array}$ \\
\hline SPI-1 & 70 & 43 & 1.6 & 6 & Apr76 to Sep76 & 7.979 & 1.330 \\
\hline SPI-3 & 84 & 27 & 3.1 & 17 & Feb77 to Jun78 & 18.312 & 1.077 \\
\hline SPI-6 & 81 & 17 & 4.8 & 27 & May76 to Jul78 & 38.261 & 1.417 \\
\hline SPI-9 & 75 & 11 & 6.8 & 37 & Jul 75 to Jul78 & 53.216 & 1.438 \\
\hline SPI-12 & 72 & 7 & 10.3 & 38 & Jul75 to Aug78 & 56.939 & 1.498 \\
\hline SPI-24 & 61 & 4 & 15.3 & 39 & May76 to Jul79 & 53.689 & 1.377 \\
\hline
\end{tabular}

The general pattern of drought and wet events for Mehalchauri station is given in Tables 9(a) and 9(b), respectively. Table 9 (a) reveals that total number of drought months reduced from 117 (SPI-1) to 101 (SPI-3 and -6); increased to 104 (SPI-12) and decreased to 103 (SPI-24). The number of drought incidents continuously decreased from 43 (SPI-1) to 4 (SPI-24); however, average duration of drought increased from 2.7 (SPI-1) to 25.8 (SPI-24) months. The longest duration of drought severity continuously increased from 8 months (SPI-1) to 43 months (SPI-24); however, average intensity varied from -0.713 (SPI-6) as mild drought to -1.049 (SPI-1) as moderate drought. It was also indicated that there were no occurrences of extreme drought out of 187 of rainfall data; however, there were 18 events $(9.6 \%)$ of severe drought and rest of the events were of mild and moderate drought. It indicates that mild drought incidents are expected to occur more frequently with short durations rather than that for long durations.

Table 9(b) indicates that the total number of wet months increased from 70 (SPI-1) to 84 (SPI-3), but decreased to 61 (SPI-24). Just like drought events, the number of wet incidents also continuously decreased from 43 (SPI-1) to 4 (SPI-24); however, average duration increased from 1.6 (SPI-1) to 15.3 (SPI-24) months. The longest duration of wet severity continuously increased from 6 months (SPI-1) to 39 months (SPI-24); however, its average intensity varied from 1.077 (SPI-3) to 1.498 (SPI-12) as moderate wet category. The extreme wet months were 45 occurrences of serious wet conditions and most of the months had mild and moderate wet conditions at Mehalchauri station. It indicates that the wet 
incidents occur more frequently with short durations rather than that for long durations at Mehalchauri station. Therefore, precautionary measures should be taken for the control of floods and water logging in the valleys along with rainwater harvesting and storage for supplemental irrigation during the periods of drought in the region.

\subsection{Prediction of Drought and Wet Events}

Month-wise probability of occurrence of meteorological drought and wet events was determined at different time-scales for all the stations and the results are as follows.

The probability analysis of meteorological drought for Naula station revealed that mean monthly probability of occurrence of mild and moderate droughts across all months varied from 0.40 to 0.51 and 0.09 to 0.14 , respectively. However, probability for severe drought varied from 0.01 to 0.03 , which is almost negligible; and the extreme drought was non-existent. Analysis of drought on seasonal basis indicated that the probability of mild-drought was 0.52 for the post-monsoon (October to January), followed by 0.47 for monsoon (June to September) and 0.40 for pre-monsoon (February to May) seasons. However, the probability of moderate drought was merely 0.14 for pre-monsoon, followed by 0.12 for post-monsoon and 0.09 for monsoon seasons. Probability of severe and extreme droughts was nearly zero.

The mean monthly probability of occurrence of wet events varied from 0.40 to 0.51 and 0.11 to 0.14 for mild and moderate, respectively. It varied merely from 0.03 to 0.07 and 0.04 to 0.06 , for severe and extreme wet events, respectively. On seasonal basis, the probability of mild-wet events was 0.28 for the pre-monsoon and monsoon seasons, followed by 0.21 for post-monsoon season. However, the mean probability of moderate wet events was only 0.08 for pre-monsoon, followed by 0.05 each for monsoon and post-monsoon seasons. Probabilities for pre-monsoon, monsoon and post-monsoon seasons were 0.04, 0.03, 0.06 and $0.04,0.05,0.05$ for severe and extreme wet events, respectively.

Nearly, the similar pattern was obtained for Kedar, Chaukhutia and Mehalchauri stations also. The results of this analysis have clearly indicated that severe and extreme drought and wet events are not a serious problem at these stations; however, there are more chances of mild and moderate drought and wet events. During wet events, the surplus water must be collected and stored by adopting appropriate rainwater harvesting and moisture conservation measures such as farm ponds, mulching, contour cultivation etc. to tackle the occasional threats of drought even during monsoon season.

\section{Conclusions}

Significantly downward trend for December and post-monsoon season and an upward trend for September were observed at Naula station. Significantly downward trend was also observed in July, December and monsoon season at Kedar station, and in June, July, August, monsoon and annual data series at Chaukhutia station. No significant trend was observed at Mehalchauri station. In general, midHimalayan region (Kedar and Chaukhutia) showed declining trend in rainfall, while the high-Himalayan region (Mehalchauri) showed no effect in rainfall trend. SPI-based drought analysis revealed that there are negligible chances of severe and extreme droughts at these stations, but more chances of mild and moderate droughts, which may be taken care of by adopting appropriate water and moisture conservation measures such as rainwater harvesting, mulching, contour cultivation etc.

\section{References}

1. S.T. Chen, C.C. Kuo and P.S. Yu, "Historical trends and variability of meteorological droughts in Taiwan," Hydrol Sci J 54(3): 430-441. 2009.

2. A.K. Mishra, V.P. Singh and V.R. Desai, "Drought Characterization: a probabilistic approach", Stoch Environ Res Risk 23(1): 41-55. 2009.

3. UN Secretariat General, "United Nations Convention to Combat Drought and Desertification in Countries Experiencing Serious Droughts and/or Desertification, Particularly in Africa, Paris. 1994.

4. R. Nagarajan, "Drought Assessment", Centre of Studies in Resources Engineering, Indian Institute of Technology, Bombay, India. 2009. 
5. S. Dogan, A. Berktay and V.P. Singh, "Comparison of multi-monthly rainfall-based drought severity indices, with application to semi-arid Konya closed basin", Turkey J Hydrol., 470: 255-268. 2012.

6. W.C. Palmer, "Meteorological droughts", US Department of Commerce, Weather Bureau. Research Paper No. 45 : 58. 1965.

7. W.J. Gibbs and J.V. Maher, "Rainfall deciles as drought indicators. Bureau of Meteorology Bulletin 48, Commonwealth of Australia, Melbourne, Australia. 1967.

8. H.N. Bhalme and D.A. Mooley, "Large-scale droughts/floods and monsoon circulation," Monthly Weather Review, 108(8): 1197-1211. 1980.

9. B.A. Shafer and L.E. Dezman, "Development of a Surface Water Supply Index (SWSI) to assess the severity of drought conditions in snowpack runoff areas". In Proceedings of the western snow conference, Fort Collins, CO: Colorado State University, Vol. 50: 164-175. 1982.

10. T.B. McKee, N.J. Doeskin and J. Kleist, "The relationship of drought frequency and duration to time scales". Proceedings of the eighth conference on applied climatology, Vol. 17. Am Meteorol Soc, Boston, MA, USA, No. 22:179-184. 1993.

11. A. Tabrizi A., D. Khalili, A.A. Kamgar-Haghighi and S. Zand-Pars, "Utilization of Time-Based Meteorological Droughts to Investigate Occurrence of Streamflow Droughts". Water Resour Manage, 24: 4287-4306. 2010.

12. J.F. Santos, M.M. Portela and I. Pulido-Calvo, "Regional frequency analysis of droughts in Portugal", Water Resour Manage, 25: 3537-3558. 2011.

13. H.R. Byun and D.A. Wilhite, "Objective quantification of drought severity and duration," J Climate 12: 27472756. 1999

14. G. Tsakiris, D. Pangalou, and H. Vangelis, "Regional drought assessment based on the Reconnaissance Drought Index (RDI)". Water Resour Manage 21(5):821-833. 2007.

15. R.P. Pandey, S.K. Mishra, R. Singh and K.S Ramasastri, "Stream flow drought severity analysis of Betwa River System (India)". Water Resour Manage, 22:1127-1141. 2008.

16. J. Keyantash and J.A. Dracup, "The quantification of drought: an evaluation of drought indices", The drought monitor. Bull Am Meteorol Soc 83(8): 1167-1180. 2002.

17. N.B. Guttman, "Comparing the Palmer drought index and the Standardized Precipitation Index", J Am Water Resour Assoc 34(1):113-121. 1998.

18. D.S. Pai, S. Latha, G. Pulak and H.R. Hatwar, "District-wide drought climatology of the southwest monsoon season over India based on standardized precipitation index (SPI)", Nat Hazards, 59: 1797-1813. 2011.

19. P. Angelidis, F. Maris, N. Kotsovinos and V. Hrissanthou, "Computation of Drought Index SPI with Alternative Distribution Functions," Water Resources Management, 26: 2453-2473. 2012.

20. Qiang Zhang, Xiao Mingzhing and Chen Xiaohong, "Regional evaluations of meteorological drought characteristics across the Pearl River basin, China". Am. J. Climate Change, 1: 48-55. 2012.

21. Palchaudhuri and Biswas, "Analysis of Meteorological Drought Using Standardized Precipitation Index - A Case Study of Puruliya District, West Bengal, India", International Journal of Environmental and Ecological Engineering, Vol. 7, No. 3: 167-174. 2013.

22. S. Sachan, T. Thomas and R. M. Singh, "Meteorological and hydrological drought characteristics in Bearma basin of Bundelkhand region in Madhya Pradesh", Indian Journal of Soil Conservation, Vol. 42, No. 2, pp 235-242. 2014.

23. Anil Kumar, "Characterizing meteorological drought using standardized precipitation index for Dehradun, Uttarakhand. Ind. J. Soil Cons., Vol. 44(2): 157-162. 2016.

24. M. Bhushan, A. Raj and L.B. Roy, "Drought and their analysis for Amritsar district in Punjab", J. Indian Water Res. Soc., Vol. 37 (3): 1-6. 2017.

25. M.G. Kendall, "Rank Correlation Methods", Charles Griffin, London. 1975.

26. P.K. Sen, "Estimates of the regression coefficient based on Kendall's tau", J Am Stat Assoc, 63 (324): 1379-1389. 1968.

27. N.L. Adhyani, T. June, and A. Sopaheluwakan, "Exposure to drought: Duration, severity, intensity" (Java, Bali Nusa Tenggara), IOP Conf. Ser.: Earth Environ. Sci. 58: 012-040. 2017. 